\title{
Information Technology Management Research of Ideological and Political Education in Graduate Students and Its Countermeasures
}

\author{
Yinghui Peng ${ }^{1, a}$ \\ ${ }^{1}$ Jiangxi Science \&Technology Normal University, Nanchang, Jiangxi, 330013 \\ a email
}

Keywords: New Era Graduate Students, Ideological and Political Education, Information Management

\begin{abstract}
In order to guide students to establish a new era of right and positive outlook on life and values, we must strengthen the ideological and political work of graduate education. In this paper, in order to promote the increase of graduate students ideological and political education levels, according to the central government to strengthen the graduate students' ideological and political education work requirements, the main issue from the present situation of ideological and political education information management graduate of the existence of a summary, reflection and Countermeasures studies in order to graduate I had ideological and political education system has improved towards more rational, scientific, pragmatic direction.
\end{abstract}

\section{Introduction}

Socialist construction of the development process, graduate students belong to one of the mainstay, so its ideological and political education becomes extremely important. Graduate with a correct outlook on life and values have on the social and economic development, social progress and other strategic influence on the development of society with strong radiation, driven and demonstration. Correct ideological and political education work will help guide the students with a firm political direction, but also to promote a comprehensive physical and moral development of students. The ideological and political education at graduate students overall have an irreplaceable role, it is an important part of graduate education.

\section{The Status of Ideological and Political Education Information Management of Graduate Student in New Age}

(1) established the position of Graduate Political Education and Moral Education. In order to strengthen and improve ideological and political education for postgraduate students and the importance of moral education, etc., to improve the overall level of postgraduate training work, various departments of the CPC Central Committee issued a document on continued with postgraduate ideological and political education and moral education, emphasizing the postgraduate education in ideological and political education in the importance of a clear ideological and political education graduate work in education came in the first place.

(2) the content of Postgraduates' Ideological and Political Education richer. Now science and technology advances, knowledge-based economy is emerging, social competition, bringing in students psychological pressure is gradually increased, and the main content of traditional graduate education includes: Mao Zedong Thought, life and values and ideological education, Graduate in Colleges for ideological and political education should be strengthened at the same time traditional ideological education work, such as: mental health counseling, communication between people, innovation and teamwork and other aspects of education should be social doctrine seriously.

After the reform and opening up, socialist country is still in transition, and international and domestic form more complex, the advantages of science and technology with Western countries, in order to achieve economic and cultural hegemony, global hegemony. Growth in the New graduate students are mostly from the "80" "90", the majority of them is an only child, grew up in the parents' favor, for larger setbacks and tests and no actual personal experience, their growth 
environment happiness is relatively simple, and therefore part of the ideals and beliefs with respect to graduate is weak, lack of confidence, deal with social problems can not be rational to look at its case do not understand the new era of life, on society the idea was biased or even extreme , lack of social confidence and conviction, to treat social problems lack of proper evaluation.

Graduate part of the learning utilitarian heart is too strong, and then lose interest in treatment research. Most of the graduate school destination just to get a diploma in social Haozhaogongzuo treat mentors and research tasks to the school, there is no course work seriously to complete, select perfunctory, thus ignoring its own research capability improvement of Graduate now appeared plagiarism, cheating, exams and other research to help people, academic fraud is not uncommon, not down to earth to complete research tasks. Now competition and social employment pressure increase year by year for graduate students, under temptation "car, house, money" become a realist, just look at the immediate interests, abandon teamwork, social responsibility mean weak. Social factors just coat layer, and the main reason is a graduate of their own problems, the education system and the whole society should pay attention to find the source of the thinking layer, addressing the root causes.

There are differences between the majority of (3) undergraduate and graduate student population. Graduate students in school longer, larger age span, followed by more personal problems; different sources of candidates, the relative dispersion, is more difficult to manage; team concept with respect to the weak, the higher level of knowledge; and graduate students representing cadres can not manage more than a very detailed understanding of everyone and everything, it is difficult to grasp many details.

\section{Improve Ideological and Political Education Work for Graduate Studies}

In the College for Graduate Political Education in the New still remain of the original basic line, principles and policies, and ideological and political education is a graduate of socialist culture builders and successors of the fundamental tasks in Colleges for graduate ideological and political education should adhere to the party leadership for graduate ideological and political education to adapt to the party work center change the transfer, to strengthen and adjust for political graduate education, improve the case of graduate students' ideological and political education work in the right direction can be taken good results can move forward in the right direction.

Important principle of ideological and political work of our Party is to respect others, caring for others, understanding of others. Therefore graduate ideological and political education should be the "people-oriented" as a graduate student ideological and political work of important guiding, content, method, pay attention to humane care, respect between teachers and students are most concerned about the actual benefits to be unrealistic to solve. For now the differences between students and teachers between the Society should respect the choice, the use of a typical demonstration, for example, communication between teachers and students and other methods to solve their ideological confusion for Graduate socialist core values of learning can not be blindly mandatory agreement, can not place the respect for differences and abandon the important value of the socialist system, the method should be equal exchange, democratic discussion and so learn to communicate.

Learning environment for learning Graduate Political Education who play an important role, and improve ideological and political education graduate learning environment for graduate study will achieve results. Graduate social work environment is indispensable ideological and political education of a place of education, which is in addition to school and learning venues outside the home, so to increase the optimization of social environment, a good educational environment for students of ideological and political education learning improved performance of the work. The school environment constitutes the various departments of the school, teaching staff, teaching facilities for postgraduate study ideological and political education work plays an important reason, one of the major venues of ideological and political education graduate school to learn, and good school spirit, deep the style of study is one of the ideological and political education graduate learning environment can not be missing in school, graduate students on campus to promote learning in good spirits. 
Improve the campus environment is a cut going to perform less urgent things, all schools should be more important sectors of the organization, held a variety of high-level cultural, entertainment and other exchange activities, so for graduate study in terms of the effective formation of a kinds of good entertainment overall learning environment. Thereby causing eventually graduate subtle process, continuously improve ideological and political education work carried out graduate study after effect, thereby resulting in the development and implementation of the ideological and political education of graduate work to achieve good results unexpected.

\section{Conclusion}

Based on the above said, ideological and political education at graduate has a wide range of factors, various factors for graduate students ideological and political education played an invaluable role in optimizing the learning environment for students of ideological and political education plays an important role, can play to good effect.

\section{References}

[1] Zhang Min. innovation Based Postgraduates' Moral Education Universities PDCA Cycle [J] Education and occupation, 2015, No. 83212:50-52.

[2] Deng Shuya, Shao Jun. Problems and Countermeasures of Graduate Political Education [J] Higher Studies, 2011, No. 21010. 157-159.

[3] Chen Li, Han Xiaomin, Zhang Zhaopeng. Reflections on the Graduate Political Education Management Model [J] Chinese and foreign entrepreneurs, 2011, No.38320: 168-169.

[4] Di Yaya. Situation of Ideological Education Shanghai College Graduate [J]. Political Lesson Study, 2014, No. 20803: 10-14. 